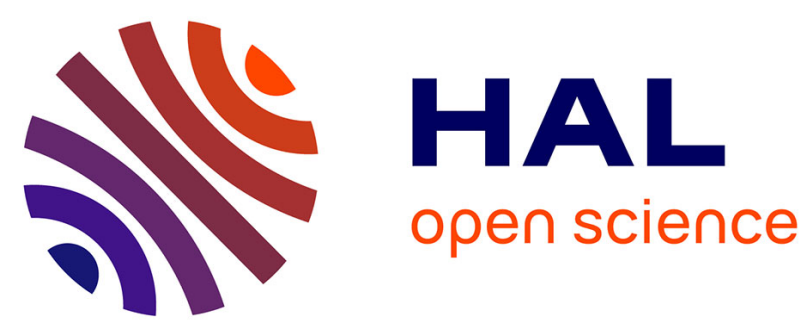

\title{
ENDOCANNABINOIDS INHIBIT RELEASE OF NERVE GROWTH FACTOR BY INFLAMMATION-ACTIVATED MAST CELLS
}

Giuseppina Cantarella, Mimmo Scollo, Laurence Lempereur, Gloria Saccani-Jotti, Francesco Basile, Renato Bernardini

\section{To cite this version:}

Giuseppina Cantarella, Mimmo Scollo, Laurence Lempereur, Gloria Saccani-Jotti, Francesco Basile, et al.. ENDOCANNABINOIDS INHIBIT RELEASE OF NERVE GROWTH FACTOR BY INFLAMMATION-ACTIVATED MAST CELLS. Biochemical Pharmacology, 2011, 82 (4), pp.380. 10.1016/j.bcp.2011.05.004 . hal-00718032

\section{HAL Id: hal-00718032 \\ https://hal.science/hal-00718032}

Submitted on 16 Jul 2012

HAL is a multi-disciplinary open access archive for the deposit and dissemination of scientific research documents, whether they are published or not. The documents may come from teaching and research institutions in France or abroad, or from public or private research centers.
L'archive ouverte pluridisciplinaire HAL, est destinée au dépôt et à la diffusion de documents scientifiques de niveau recherche, publiés ou non, émanant des établissements d'enseignement et de recherche français ou étrangers, des laboratoires publics ou privés. 


\section{Accepted Manuscript}

Title: ENDOCANNABINOIDS INHIBIT RELEASE OF NERVE GROWTH FACTOR BY INFLAMMATION-ACTIVATED MAST CELLS

Authors: Giuseppina Cantarella, Mimmo Scollo, Laurence Lempereur, Gloria Saccani-Jotti, Francesco Basile, Renato

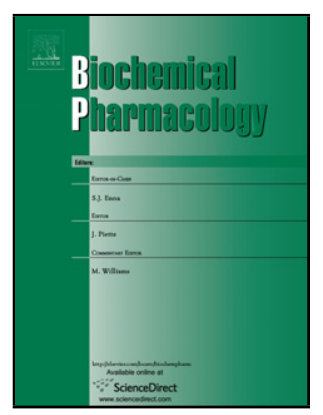

Bernardini

PII:

S0006-2952(11)00297-8

DOI: doi:10.1016/j.bcp.2011.05.004

Reference: BCP 10896

To appear in: $\quad B C P$

Received date: $\quad$ 9-3-2011

Revised date: $\quad 4-5-2011$

Accepted date: $\quad$ 5-5-2011

Please cite this article as: Cantarella G, Scollo M, Lempereur L, Saccani-Jotti $\mathrm{G}$, Basile $\mathrm{F}$, Bernardini R, ENDOCANNABINOIDS INHIBIT RELEASE OF NERVE GROWTH FACTOR BY INFLAMMATION-ACTIVATED MAST CELLS, Biochemical Pharmacology (2010), doi:10.1016/j.bcp.2011.05.004

This is a PDF file of an unedited manuscript that has been accepted for publication. As a service to our customers we are providing this early version of the manuscript. The manuscript will undergo copyediting, typesetting, and review of the resulting proof before it is published in its final form. Please note that during the production process errors may be discovered which could affect the content, and all legal disclaimers that apply to the journal pertain. 


\section{ENDOCANNABINOIDS INHIBIT RELEASE OF NERVE GROWTH FACTOR BY INFLAMMATION-ACTIVATED MAST CELLS}

Giuseppina Cantarella ${ }^{1}$, Mimmo Scollo ${ }^{1}$, Laurence Lempereur ${ }^{1}$, Gloria Saccani-Jotti ${ }^{2}$, Francesco Basile $^{3} \&$ Renato Bernardini ${ }^{1}$

${ }^{1}$ Department of Experimental and Clinical Pharmacology, University of Catania School of Medicine, Catania, Italy; ${ }^{2}$ Department of Public Health, University of Parma School of Medicine, Parma, Italy; ${ }^{3}$ Department of Surgery, University of Catania School of Medicine, Catania, Italy

Running Title: Endocannabinoids inhibit mast-cell NGF release

Corresponding Author:

Prof. Renato Bernardini, MD

Dept. of Experimental and Clinical Pharmacology

University of Catania School of Medicine

Viale Andrea Doria 6

95125 Catania

Italy

Ph: $+39-095-7384090$

Fax: +39-095-7384229

Email: bernardi@unict.it 


\begin{abstract}
Nerve growth factor (NGF) is a pleiotropic member of the neurotrophin family. Beside its neuronal effects, NGF plays a role in various processes, including angiogenesis. Mast cells release NGF and are among elements contributing to angiogenesis, a process regulated by arrays of factors, including the inhibitory cannabinoids. The possible inhibitory role of cannabinoids on mast cellrelated NGF mitogenic effect on endothelial cells was then investigated. Human mastocytic cells HMC-1, challenged with PMA to yield release of NGF, were preincubated with the endocannabinoid PEA. Then, conditioned media were added to HUVEC cultures. PMA-activated HMC-1 cells released substantial amounts of NGF, whereas PEA inhibited PMA-induced NGF release. HUVEC proliferation increased after treatment with media from activated HMC-1 cells, while was reduced with media from HMC-1 cells treated with PEA. To characterize receptors mediating such effects of PEA, RT-PCR and western blot analysis were performed on HMC-1 cells. None of the two cannabinoid $\mathrm{CB} 1$ and $\mathrm{CB} 2$ receptors was expressed by HMC-1 cells, which on the other hand expressed the orphan receptor GPR55. PEA was ineffective in inhibiting NGF release from HMC-1 cells treated with PMA and transfected with positive GPR55 RNAi, whereas it induced significant reduction of NGF in cells transfected with the corresponding negative control RNAi. Results indicate that NGF released from inflammatory mast cells induces angiogenesis. Cannabinoids attenuate such pro-angiogenic effects of NGF. Finally, cannabinoids could be considered for antiangiogenic treatment in disorders characterized by prominent inflammation.
\end{abstract}

Key words: Endocannabinoids, NGF-related inflammation, receptor, antagonist 


\section{INTRODUCTION}

Nerve growth factor (NGF) is the prototype molecule for the family of neurotrophins [1], of primary relevance to neurogenesis [2], neuronal repair processes [3], as well as neuronal plasticity [4] and survival.

Although neurotrophins are thought to exert their actions predominantly on neural cells [5], indeed some of them possess pleiotropic properties [6]. For example, NGF is able to exert proinflammatory effects [7] and displays prominent pro-angiogenic properties in vitro and in vivo [8].

Moreover, NGF can influence development and activation of an array of haematopoietic cell types, including basophiles and mast cells [9]. Interestingly, the latter can release substantial amounts of NGF stored in their granules [10]. Mast cells are derived from their haematopoietic precursors and represent critical effectors cells in allergic disorders and other IgE-dependent immune responses [11]. More recently, it has been shown that mast cells are also involved in the regulation of angiogenesis [12], the process leading to formation of new vessels starting from preexisting ones [13].

From the biologic point of view, angiogenesis is the result of the concerted, balanced action of an array of stimulatory factors, such as, for instance, VEGF or FGF [14], or inhibitory factors of various nature, including angiostatin [15], endostatin [16], and the family of ubiquitary lipid mediators known as endocannabinoids [17, 18].

Endocannabinoids usually induce inhibitory responses in different tissues and organs [18], their effects being mediated by specific membrane receptors, such as those belonging to the CB1/CB2 system [19-20], vanilloid receptors [21], and the TRPV1 receptor. Recently, a novel receptor, which is able to bind endocannabinoids, GPR55, has been identified and cloned [22].

In this paper, we describe the role of NGF released by noxious stimuli-activated mast cells in fuelling angiogenesis and, eventually, the modulating effects of the endocannabinoid PEA, an Nacylamidic molecule that negatively influences mast cell functions sustaining an inflammatory response [23]. 
To demonstrate the hypothesized angiogenic potential of mast cells, we first challenged the one-of-a kind human cell line, derived from a patient with mast cell leukaemia, mastocytic cells HMC-1 [24] with inflammatory stimuli and then measured NGF released in the media. Subsequently, human umbilical cord vascular endothelial cells (HUVEC) underwent challenge with conditioned media from activated mast cells.

Finally, in light of the described inhibitory effects of cannabinoids upon inflammation [18], we evaluated possible inhibitory effects of PEA on mast cells-related NGF release. 


\section{MATERIALS AND METHODS}

\subsection{Cell cultures and reagents.}

HMC-1 cells (kindly provided by Dr. Butterfield, Rochester, MN), which are immature human leukemic mast cells, were cultured in Iscove's medium, supplemented with $10 \%$ fetal calf serum (FCS) (Invitrogen Srl, San Giuliano Milanese, Italy), $10 \mathrm{mM}$ monothiolglycerol (SigmaAldrich, Milano, Italy), and antibiotics (streptomycin and penicillin) (Sigma-Aldrich, Milano, Italy). Stimulation of HMC-1 cells was performed in 24-multiwell plates (Falcon, Lincoln Park, NJ). Before stimulation, cells were cultured for $24 \mathrm{~h}$ in medium without FCS. After this time, $2 \times 10^{6}$ cells were incubated for the times indicated in medium without FCS containing different concentration of PMA (Sigma-Aldrich, Milano, Italy), or PEA (kindly provided by Dr. Della Valle, Epitech, Italy) or combination of both substance.

HUVECs were obtained from human umbilical cords from healthy women underwent uncomplicated term pregnancies, as described elsewhere [25].

Cells were grown in gelatin coated plastic in medium M199 (Invitrogen Srl, San Giuliano Milanese, Italy) (Invitrogen Srl, San Giuliano Milanese, Italy) supplemented with endothelial cell growth supplement (ECGS; $20 \mu \mathrm{g} / \mathrm{ml}$ ) (Sigma-Aldrich, Milano, Italy), heparin (1625 UI/ml) (SigmaAldrich, Milano, Italy) and $20 \%$ fetal calf serum (FCS) (Invitrogen Srl, San Giuliano Milanese, Italy) •

\subsection{ELISA}

The secretion of NGF in the culture media after different treatments was measured with growth factor specific ELISA kits (Quantikine, RD Systems Inc. Minneapolis, MN, USA), according to the instructions of the manufacturer. The lower detection limit for NGF was $5 \mathrm{pg} / \mathrm{ml}$. Concentrations of NGF in the samples were calculated by interpolation from the standard curve.

\subsection{Western blot analysis}

Proteins obtained after different treatments, according to the experiment, were separated in acrylamide gels and electrotransferred to nitrocellulose blots (Amersham Italia S.r.l., Milan, Italy). 
Membranes were incubated with 5\% fat-free milk, 0.1\% Tween-20 (Sigma-Aldrich, Milano, Italy) in PBS (Sigma-Aldrich, Milano, Italy) and incubated with the following antibodies: rabbit polyclonal anti NGF (Santa Cruz Biotechnology, Santa Cruz, CA, USA) rabbit polyclonal anti CB1 (Cayman chemical Ann Arbor, MI, USA), rabbit polyclonal anti CB2 (Cayman chemical Ann Arbor, MI, USA), rabbit polyclonal anti GPR55 (Abcam, Cambridge, UK), or rabbit polyclonal anti $\beta$-tubulin (Santa Cruz Biotechnology, Santa Cruz, CA, USA) . Peroxidase-labeled secondary antibodies and an enhanced chemiluminescence kit (Amersham Italia S.r.l., Milan, Italy) were used for immunodetection. For validation of blot data, densitometric analysis was performed on immunoblots by using ImageJ analysis software.

\subsection{Immunofluorescence.}

HCM-1 cells grown on tissue culture chamber slides after different treatments were fixed with $4 \%$ paraformaldehyde (Sigma-Aldrich, Milano, Italy) for $15 \mathrm{~min}$, followed by permeabilization with 0.1\% Triton X-100 (Sigma-Aldrich, Milano, Italy) and blocking for 45 min with PBS-BSA $1 \%$ (Sigma-Aldrich, Milano, Italy). The cells were consecutively processed with rabbit polyclonal anti NGF (Santa Cruz Biotechnology, Santa Cruz, CA, USA) or rabbit polyclonal anti GPR55 (Abcam, Cambridge, UK) or isotype control antibody, and anti-rabbit antibody-fluorescein isothiocyanate (FITC) conjugate (Serotec Ltd., Oxford, England). Cells were observed under fluorescence light microscope (DMIRB, Leica, Germany) and photographed.

\subsection{HUVEC proliferation assay}

For human umbilical endothelial cell (HUVEC) proliferation studies the conditioned medium (CM) of unstimulated and PMA 50ng/ml (Sigma-Aldrich, Milano, Italy) stimulated cells was used alone. For this purpose, HMC-1 cells were cultured for $24 \mathrm{~h}$ under the same conditions as described above. CM was concentrated 10-fold by ultrafiltration in Centriprep-10 filter units (Amicon, Beverly, MA), and supernatants were stored frozen at $-80^{\circ} \mathrm{C}$. HUVEC were seeded at $1 \times 10^{3}$ cells/well into 96-multiwell plates in M199 with ECGS, $20 \%$ FCS and heparin. After 24 h, medium was replaced with fresh complete medium containing graded concentrations of $\mathrm{CM}(10,20,40$ and $80 \%$ of $\mathrm{CM})$ 
and incubated for $96 \mathrm{~h}$. In other experiment NGF neutralizing antibodies $(1 \mu \mathrm{g} / \mathrm{ml})(\mathrm{R} \& \mathrm{D}$ Systems, Inc. Minneapolis, MN, USA) were added together with $(10,20,40$ and $80 \%$ of CM) to HUVECs and incubated along the entire experiment. In other experiments HUVEC were treated with PEA 50 $\mu \mathrm{g} / \mathrm{ml}$, or PMA $50 \mathrm{ng} / \mathrm{ml}$ or with the combination of both substance.

At the end of experiments cells were stained with $0.5 \%$ crystal violet solution for $30 \mathrm{~min}$, washed with bidistilled water and lysed in $10 \%$ acetic acid for $15 \mathrm{~min}$. Optical density was read at $570 \mathrm{~nm}$.

\subsection{Reverse transcriptase-PCR.}

Total RNA was extracted from cells grown to $80 \%$ confluence using TRIzol (Invitrogen Srl, San Giuliano Milanese, Italy), according to the manufacturer's instructions. For first strand cDNA synthesis, $1 \mu \mathrm{g}$ of total RNA was reverse-transcribed using $25 \mu \mathrm{g} \mathrm{ml}-1$ oligo (dT)12-18 primer (Invitrogen Srl, San Giuliano Milanese, Italy) in a final volume of $20 \mu 1$, in the presence of 200 units of M-MLV reverse (Invitrogen Srl, San Giuliano Milanese, Italy). The reaction was carried out at $37{ }^{\circ} \mathrm{C}$ for $1 \mathrm{~h}$ and heated at $95{ }^{\circ} \mathrm{C}$ for $10 \mathrm{~min}$, and subsequently for $5 \mathrm{~min}$ at $4{ }^{\circ} \mathrm{C}$. The reaction program for (a) human $\mathrm{CB} 1$ and human $\mathrm{CB} 2$ primers consisted of 35 runs of denaturation at $95{ }^{\circ} \mathrm{C}$ for $45 \mathrm{sec}$, annealing at $62{ }^{\circ} \mathrm{C}$ for $45 \mathrm{sec}$ and elongation at $72{ }^{\circ} \mathrm{C}$ for $1 \mathrm{~min}$.; (b) human GPR55 primers consisted of denaturation at $95^{\circ} \mathrm{C}$ for $45 \mathrm{sec}$, annealing at $56^{\circ} \mathrm{C}$ for $45 \mathrm{sec}$ and elongation at $72^{\circ} \mathrm{C}$ for $1 \mathrm{~min}$. The cycle program was preceded by an initial denaturation at $95{ }^{\circ} \mathrm{C}$ for $3 \mathrm{~min}$ and followed by a final extension at $72{ }^{\circ} \mathrm{C}$ for $7 \mathrm{~min}$. PCR products were analyzed by $1.0 \%$ agarose gel electrophoresis and visualized with ethidium bromide. The following RNA transcripts were detected via amplification of the corresponding cDNAs: the human CB1 using a primer pair composed of the sense primer 5'-CATCATCACACGTCTG-3' and the antisense primer 5'-ATGCTGTTATCCAGAGGCTGC-3'; the human CB2 using a primer pair composed of the sense primer 5'-TTTCCCACTGATCCCCAATG-3' and the antisense primer 5'AGTTGATGAGGCACAGCATG-3'; the human GPR55 using a primer pair composed of the sense primer 5'- GAGTCAGCAAAACACCAGTGGGGAC -3' and the antisense primer 5'GTGGTCTCGGCGGCCCAGCAGGATC -3’. 


\subsection{RNA interference (RNAi) analysis.}

GPR55-expressing HMC1 cells were transfected with duplex small interfering RNA (siRNA) (Invitrogen Srl, San Giuliano Milanese, Italy) for GPR55 using Lipofectamine RNAiMAX (Invitrogen Srl, San Giuliano Milanese, Italy) reagent according to the manufacturer's instructions. Following transfection, the cells were incubated at $37{ }^{\circ} \mathrm{C}$ for $24 \mathrm{~h}$. The sequences of the siRNA used were as follows; sense, 5'-AGGUGUUUGGCUUCCUCCUUCCCAU-3'; antisense, 5'-AUG GGAAGGAGGAAGCCAAACACCU-3'. The stealth RNAi negative control duplex, whose GC content is similar to that of the duplex siRNA, was used as a negative control.

\subsection{Statistical analysis}

All experiments were perfomed in triplicate. Results were analyzed by the one-way ANOVA, followed by the least significance Duncan's test. Vertical bars in figures are means + S.E of at least three separate experiments was set at a $p$-value $<0.05$. 


\section{RESULTS}

\subsection{Nerve growth factor is substantially released by human mast cells challenged with inflammatory stimuli}

In order to assess the ability of the human mast cell line HMC-1, cultures were incubated $24 \mathrm{~h}$ with graded concentrations of the pro-inflammatory compound phorbol myristate acetate (PMA), an activator of protein kinase C. PMA induced robust release of NGF by HMC-1 cells in a concentration-dependent manner. The most effective NGF releasing concentration of PMA was 50 $\mathrm{ng} / \mathrm{ml}$ (fig. 1, panel A). The release induced by PMA (50 ng/ml) was also time dependent, as incubation of HMC-1 cells resulted in significantly increased levels of tissue culture media NGF after $8 \mathrm{~h}$, reaching a maximum after $24 \mathrm{~h}$ incubation as assessed by ELISA assay of the tissue culture media. The expression of NGF was also assessed by western blot at identical time points in respective cell lysates; data obtained indicated that NGF content of HMC-1 cell was partially depleted after $8 \mathrm{~h}$ incubation, and totally after $24 \mathrm{~h}$ incubation, in a way inversely proportional to the amounts of NGF released into the tissue culture media (Fig. 2, panels A and B).

\subsection{Endocannabinoids modulate NGF release by HMC-1 cells.}

In view of the pro-inflammatory role of NGF contained in mast cells, as well as of the inhibitory effects of endocannabinoids upon various inflammatory parameters, the effects of the endocannabinoid derivative PEA was assessed in the model of PMA-induced NGF release, in cultured HMC-1 cells. Incubation of HMC-1 cells with graded concentrations of the cannabinoid related molecule palmithoylethanolamide (PEA) prevented the increase of NGF release in the tissue culture media determined by phorbol myristate acetate (PMA), as assessed by ELISA assay (Fig. 3). The most effective concentration of PEA was $50 \mu \mathrm{g} / \mathrm{ml}$. In the same line, previous results inverse pattern of NGF expression was found in HMC-1 cell lysates undergone western blot analysis (Fig. 4, panel A and B)

In addition to ELISA and western blot data, HMC-1 cells were incubated with PEA $50 \mu \mathrm{g} / \mathrm{ml}$, and then challenged with a specific anti-NGF fluorescent antibody. Data obtained indicate that, whereas 
treatment of cells with PMA depletes intracellular NGF from mast cells, pre-treatment of cells with PEA resulted in substantial prevention of NGF depletion from HMC-1 cells (Fig. 5).

\subsection{NGF release by activated mast cells is associated with proliferation of endothelial cells.}

Considering the role of mast cells in inflammatory phenomena of various origins [26], and that NGF contributes to angiogenesis processes [8], we attempted to establish a role for mast cellreleased NGF in relation to different parameters related to endothelial cell biology.

To do so, HMC-1 cells were first treated with PMA to allow de-granulation and consequent NGF release. Then, graded concentrations of supernatants were added to the usual incubation media of HUVEC cells.

HUVEC treated with concentrated supernatants from PMA-challenged HMC-1 responded with increased proliferation (Fig. 6, panel A). The addition to the tissue culture media of either a NGF monoclonal antibody, or PEA prevented the increased mitogenesis of HUVEC cells observed after addition of activated HMC-1 cell-conditioned medium (Fig. 6, respectively panels B and C).

\subsection{The blunting effects of PEA on mast cell NGF release are mostly mediated by the GPR55} orphan receptor.

In order to unravel molecular mediators and mechanisms underlying the effects of PEA on mast cell-dependent NGF release, investigation continued focusing on cannabinoid-related receptors pattern in HMC-1 cells.

RT-PCR mRNA analysis for CB1 and CB2 receptors revealed that the human mast cell line HMC-1 lacks both receptors, as compared to the control human neuronal cell line HNC (human neuronal cells)(Fig. 7, panel A) mRNA data corresponded with western blot analysis, which indicated the absence of both receptor protein in HMC-1 cells (Fig. 7, panel B).

Thus, with the aim to elucidate the possible mechanisms responsible for PEA effects in PMA stimulated HMC-1 cells, a new member of the cannabinoid receptor family, the orphan receptor GPR55, was analyzed in HMC-1 cells. Either GPR55 mRNA (RT-PCR; fig. 7, panel C) or protein (western blot; fig. 7, panel D) were detected in HMC-1 cells. 


\subsection{The GPR55 orphan receptor is specifically relevant to pharmacological modulation of mast cell-dependent NGF release.}

To answer the question whether or not the GPR55 orphan receptor could play a functionally relevant role in mediating the inhibiting effects of PEA, we then investigated consequences of GPR55 receptor blockade on mast cell-related NGF release in HMC-1 cells. To do so, cells were first transfected either with the positive GPR55 $\mathrm{RNAi}^{+}$, or with its corresponding negative GPR55 RNAi-

Incubation of HMC-1 cells with GPR55 $\mathrm{RNAi}^{+}$, resulted in time dependent decrease of GPR55 receptor protein expression. Western blot analysis of HMC-1 cell lysates revealed maximal effect of GPR55 $\mathrm{RNAi}^{+}$occurred after $48 \mathrm{~h}$ incubation, whereas GPR55 protein expression returned to basal values after $72 \mathrm{~h}$ of incubation with the positive GPR55 $\mathrm{RNAi}^{+}$(Fig. 8, upper and lower blots).

Similar results were obtained by using immunofluorescence methods, using a specific GPR55 monoclonal antibody (data not shown).

Moreover, to provide the proof of concept that GPR55 orphan receptor is functionally enrolled in mast cell-dependent NGF release, the latter was assayed in the tissue culture media of HMC-1 cells that had been transfected with either GPR55 RNAi ${ }^{+}$, or GPR55 RNAi , in various experimental conditions. In fact, PEA was ineffective in lowering amounts of NGF released into the media in HMC-1 cells treated with PMA, transfected with GPR55 RNAi ${ }^{+}$, whereas it was able to induce significant reduction of NGF in those transfected with the negative GPR55 RNAi- (Fig. 9). 


\section{DISCUSSION}

In this paper, we demonstrate that nerve growth factor release from mast cells activated by inflammatory stimuli is inhibited in the presence of PEA, a lipid molecule belonging to the endocannabinoid family.

It is known that NGF is released by activated immunocytes and may mediate inflammatory reactions [27]. In this line, an increased number of polymorphonucleate cells are observed in animal models of inflammation [28], and the neurotrophin possesses hyperalgesic properties as assessed by various tests for pain score in laboratory species, as well as in humans. [29-30]. In addition, NGF has been shown to fuel the inflammatory angiogenic process through its mitogenic effects upon endothelial cells [8].

In line with these current literature reports, the application of the pro-inflammatory molecule PMA to cultured human mastocytic cells HMC-1 induces time-related release of NGF. Maximal release was observed after $24 \mathrm{~h}$ incubation with PMA.

Now, evidence shows that inflammatory processes may be delayed after the occurrence of a noxious stimulus [31]. For example, mast cells increase their number and are activated following allergen or bacterial lipopolysaccharide challenge [32], as well as in increasing post-traumatic or post-ischemic inflammatory events [33]. It is in fact common notion that a quantitative evaluation of the real damage consequent to application of noxious stimuli is reasonable after one day or more from damage [34]. For example, in nervous trauma, this is the consequence of the progressive recruiting of neurons to apoptotic phenomena, which are triggered with the traumatic event and eventually progress in following hours [33]. Thus, it is plausible to hypothesize that mast cells activated by aspecific inflammatory stimuli release mediators of inflammation, including NGF, with a delayed schedule if compared to other cells, such as neutrophils that are instead promptly recruited to the inflammatory site shortly after application of noxae [35]. In our hands, immunofluorescence experiments indicated that granules of HMC-1 cells were depleted of NGF concomitantly with increased levels of the neurotrophin into the culture media. 
Thus, as endocannabinoids have been proven to physiologically exert anti-inflammatory effects [33], it appears plausible that incubation of PMA-challenged HMC-1 cells with the endocannabinoid-related lipid molecule PEA, resulted in decreased release of NGF into the culture media and, in parallel, in decreased degranulation of mast cells, thus preventing detrimental effects of NGF and other mediators released abundantly following their activation during inflammatory processes [29].

Post-traumatic or - ischemic inflammation may be associated with progressive cell loss and proliferation of non-specific cell elements, such as fibroblasts [36], as well as with neoangiogenesis [37]. The latter would either take place in response to vasoactive stimuli which occur in the inflammatory process, or by hypoxia and is nevertheless fuelled by overproduction of proangiogenic molecules, such as NGF [37].

In this line, tissue culture media conditioned by mast cells activated with PMA were able to promote endothelial cell proliferation. The mitogenic potential of conditioned media was however blunted when endothelial cells had been pre-treated with a specific NGF monoclonal antibody, thus corroborating the NGF hypothesis of angiogenesis promotion. In fact, it has been reported that HUVEC express the NGF specific tyrosine kinase receptor trk140, which mediates mitogenesis of endothelial cells in vitro and formation of new vessels in vivo $[2,8]$.

When inflammatory angiogenesis is triggered, formation of new vessels is however the result of the balanced action of multiple factors of either stimulatory or inhibitory nature [13]. Thus, besides VEGF, FGF [14], or NGF [8], endothelial cells are under the influence of angiostatin [15], endostatin [16], or endocannabinoids [17].

We observed that the pharmacological endocannabinoid compound PEA eventually slowered HUVEC cell proliferation in a fashion similar to the anti-NGF monoclonal antibody. These data not only suggest that endocannabinoids exert antinflammatory effects [38], but that these molecules also restrain angiogenic processes eventually occurring during an inflammatory process. In addition, as cannabinoid derivative have been suggested and/or approved for clinical use in 
various pathological conditions, such as multiple sclerosis (MS) [39] and gastrointestinal and liver diseases [40], one could envision their use as anti-mast cell/NGF component of inflammation.

Now one reasons that anti-inflammatory effects of cannabinoids are mostly mediated by the CB1/CB2 family of cannabinoid receptors [41]. However, no expression of these two receptors was detected in HMC-1 cells [42]. Thus, in line with the hypothesis that some effects of endocannabinoids are mediated by the GPR55 receptor [22], either GPR55 mRNA and protein were detected in HMC-1 cells. These finding are in accordance with other work, describing GPR55 expression in other cell type of the immune system, such as microglia [43], and led to the hypothesis that they could indeed play a functional role.

Results showed that inhibition of GPR55 protein synthesis occurs in HMC-1 cells transfected with the GPR55 $\mathrm{RNAi}^{+}$, and that PEA is very ineffective in blunting NGF levels in the media from cells bearing the GPR55 $\mathrm{RNAi}^{+}$transfection. These data strongly suggest that the GPR55 orphan receptor is responsible for the majority of the inhibiting effects of PEA on PMA induced release of NGF from activated mast cells.

In synthesis, these data are suggestive for a substantial contribution of NGF to the inflammatory activity of mast cells in the human cell line $\mathrm{HMC}-1$ and that, in particular, it also exerts a potent proliferative effect upon human endothelial cells, the first phase of angiogenesis. Cannabinoids, such as PEA, effectively inhibit NGF release from mast cells and consequent endothelial cell proliferation, an effect mediated by the orphan receptor GPR55.

In conclusion, we hypothesize that inhibition of the GPR55 receptor might be envisioned as a novel candidate mode for treatment of human inflammatory disorders of various origins, by restraining the angiogenic component. 


\section{ACKNOWLEDGEMENTS}

This work was accomplished thanks to generous contribution of the Epitech group inc., Abano Terme, and, in part, with the funds granted by MIUR to the PhD school in Preclinical and Clinical Pharmacology, University of Catania School of Medicine. 


\section{REFERENCES}

[1] Thoenen H. The changing scene of the neurotrophic factors. Trends Neurosci. 1991; 14:165-70.

[2] Jiang H, Movsesyan V, Fink Jr DW, et al. Expression of human p140trk receptors in p140trkdeficient, PC12/endhotelial cells resulting nerve growth factor-induced signal transduction and DNA synthesis. J Cell Biochem. 1997; 66: 229-44.

[3] Tabakman R, Lecht S, Sephanova S, et al.. Interactions between the cells of the immune and nervous system:neurotrophins as neuroprotection mediators in CNS injury. Progr Brain Res. 2004; 146:387-401.

[4] Glebova NO, Ginty DD. Heterogeneous requirement of NGF for sympathetic target innervation in vivo. J Neurosci. 2004; 24:743-51.

[5] Levi-Montalcini R. The nerve growth factor 35 years later. Science. 1987; 37:1154-62.

[6] Tuveri M, Generini S, Matucci-Cerinic M, Aloe L. NGF, a useful tool in the treatment of chronic vasculitic ulcers in rheumatoid arthritis. Lancet. 2000; 356:1739-40.

[7] Raychaudhuri SK, Raychaudhuri SP, Weltman H, Farber EM. Effect of nerve growth factor on endothelial cell biology: proliferation and adherence molecule expression on human dermal microvascular endothelial cells. Arch Dermatol Res. 2001; 293: 291-5.

[8] Cantarella G, Lempereur L, Presta M, et al. Nerve growth factor-endothelial cell interaction leads to angiogenesis in vitro and in vivo. FASEB J. 2002; 16: 1307-9.

[9] Crivellato E, Travan L, Ribatti D. Mast Cells and Basophils: A Potential Link in Promoting Angiogenesis during Allergic Inflammation. Int Arch Allergy Immunol. 2010; 151: 89-97.

[10] Nilsson G, Forsberg-Nilsson K, Xiang Z, et al. Human mast cells express functional TrkA and area source of nerve growth factor. Eur J Immunol. 1997; 27: 2295-301.

[11] Nadler MJ, Matthews SA, Turner H, Kinet JP. Signal transduction by the high-affinity immunoglobulin E receptor FceRI: coupling form to function. Adv Immunol. 2000; 76: 325-55.

[12] Maltby S, Khazaie K, McNagny KM. Mast cells in tumor growth: Angiogenesis, tissue remodelling and immune-modulation. Biochim Biophys Acta. 2009; 1796:19-26. 
[13] Folkman J. Angiogenesis in cancer, vascular, rheumatoid and other disease. Nat Med. 1995; 1: 27-32.

[14] Ferrara N, Houck K, Jakeman L, Leung DW. Molecular and biological properties of the vascular endothelial growthfactor family of proteins. Endocr Rev. 1992; 13:18-32.

[15] Ribatti D.. Endogenous inhibitors of angiogenesis: a historical review. Leuk Res. 2009; 33: 638-44.

[16] O'Reilly MS, Boehm T, Shing Y, et al. Endostatin: anendogenous inhibitor of angiogenesis and tumor growth. Cell. 1997; 88: 277-85.

[17] Bifulco M, Laezza C, Gazzerro P, Pentimalli F. Endocannabinoids as emerging suppressors of angiogenesis and tumor invasion . Oncol Rep. 2007; 17: 813-6.

[18] Di Marzo V. Targeting the endocannabinoid system: to enhance or reduce? Nat Rev Drug Discov. 2008; 7: 438-55.

[19] Matsuda LA, Lolait SJ, Brownstein MJ, et al. Structure of a cannabinoid receptor and functional expression of the cloned cDNA. Nature. 1990; 346: 561-4.

[20] Munro S, Thomas KL, Abu-Shaar M, Molecular characterization of a peripheral receptor for cannabinoids. Nature. 1993; 365: 61-5.

[21] De Petrocellis L, Vellani V, Schiano-Moriello A, et al. Plant-Derived Cannabinoids Modulate theActivity of Transient Receptor Potential Channels of Ankyrin Type-1and Melastatin Type-8. J Pharmacol Exp Ther. 2008; 325: 1007-15.

[22] Ryberg E, Larsson N, Sjögren S, et al. The orphan receptor GPR55 is a novel cannabinoid receptor. Br J Pharmacol. 2007; 152: 1092-101.

[23] Mazzari S, Canella R, Petrelli L, et al. N-(2-hydroxyethyl)hexadecanamide is orally active in reducing edema formation and inflammatory hyperalgesia by down-modulating mast cell activation. Eur J Pharmacol. 1996; 300: 227-36.

[24] Butterfield JH, Weiler DA, Hunt LW, et al. Purification of tryptase from a human mast cell line. J Leukoc Biol. 1990; 47: 409-19. 
[25] Jaffe EA, Nachman RL, Becker CG, Minick CR. Culture of human endothelial cells derived from umbilical veins. Identification by morphologic and immunologic criteria. J. Clin. Invest. 1973; 52: $2745-56$

[26] Gribaldeston MA, Metz M, Yu M, et al. Effector and potential immunoreg-ulatory roles of mast cells in IgE-associated acquired immune responses. Curr Opin Immunol. 2006; 18: 751-60.

[27] Aloe L, Bracci-Laudiero L, Bonini S, Manni L. The expanding role of nerve growth factor: from neurotrophic activity to immunologic diseases. Allergy. 1997; 52: 883-994.

[28] Metcalfe DD, Baram D, Mekori YA. Mast cells Physiol Rev. 1997; 77:1033-79.

[29] Dmitrieva N, McMahon SB. Sensitisation of visceral afferents by nerve growth factor in the adult rat. Pain. 1996; 66: 87-97.

[30] Farquhar-Smith WP, Rice AS. A novel neuroimmune mechanism in cannabinoid-mediated attenuation of nerve growth factor-induced hyperalgesia. Anesthesiology. 2003; 99: 1391-401.

[31] Williams CM, Galli SJ. The diverse potential effector and immunoregulatory roles of mast cells in allergic disease. J Allergy Clin Immunol. 2000;105: 847-59.

[32] Li Q, Whitcup SM, Fujino Y, et al. The role of mast cells in endotoxin-induced uveitis. Invest Ophthalmol Vis Sci. 1993; 34: 256-9.

[33] Costa B, Conti S, Giagnoni G, Colleoni M. Therapeutic effect of the endogenous fatty acid amide, palmitoylethanolamide, in rat acute inflammation: inhibition of nitric oxide and cyclooxygenase systems. Br J Pharmacol. 2002;137: 413-20.

[34] Di Rosa M, Giroud JP, Willoughby DA. Studies on the mediators of the acute inflammatory response induced in rats in different sites by carrageenan and turpentine. J Pathol. 1971; 104:15-29.

[35] Chen M, Lam BK, Kanaoka Y, et al. Neutrophil-derived leukotriene B4 is required for inflammatory arthritis. J Exp Med. 2006; 203: 837-42.

[36] Badid C, Mounier N, Costa AM, Desmoulière A. Role of myofibroblasts during normal tissue repair and excessive scarring: interest of their assessment in nephropathies. Histol Histopathol. 2000; 15: 269-80. 
[37] Emanueli C, Salis MB, Pinna A, et al. Nerve growth factor promotes angiogenesis and arteriogenesis in ischemic hind limbs. Circulation. 2002; 106: 2257-62.

[38] Lambert DM, Vandevoorde S, Jonsson KO, Fowler CJ. The palmitoylethanolamide family: a new class of anti-inflammatory agents?. Curr Med Chem. 2002; 9: 663-74.

[39] Rog DJ. Cannabis-based medicines in multiple sclerosis-a review of clinical studies. Immunobiology. 2010; 215: 658-72.

[40] Izzo AA, Camilleri M. Emerging role of cannabinoids in gastrointestinal and liver diseases: basic and clinical aspects. Gut. 2008; 57: 1140-55.

[41] Bolognini D, Costa B, Maione S, et al. The plant cannabinoid Delta9-tetrahydrocannabivarin can decrease signs of inflammation and inflammatory pain in mice. Br J Pharmacol. 2010; 160: 677-87.

[42] Maccarrone M, Fiorucci L, Erba F, et al. Human mast cells take up and hydrolyze anandamide under the control of 5-lipoxygenase and do not express cannabinoid receptors. FEBS Lett. 2000; 468: 176-80.

[43] Pietr M, Kozela E, Levy R, et al. Differential changes in GPR55 during microglial cell activation. FEBS Lett. 2009; 583: 2071-6. 


\section{FIGURE LEGENDS}

Figure 1. Nerve growth factor (NGF) amounts measured in the tissue culture media of human mastocytic HCM-1 cells challenged with graded concentrations of the phorbol esther phorbol myristate acetate (PMA). Vertical bars are means \pm SE; *p $<0.05$ vs. CTRL (one-way ANOVA followed by the least significance Duncan's test). CTRL: Untreated cells.

Figure 2. Panel A: Time-dependent effect of the phorbol esther phorbol myristate acetate (PMA; $50 \mathrm{ng} / \mathrm{ml}$ ) upon NGF release in the media from cultured human mastocytic HCM-1 cells. Vertical bars are means $\pm \mathrm{SE}$; ${ }^{*} \mathrm{p}<0.05 v s$. CTRL (one-way ANOVA followed by the least significance Duncan's test). CTRL: untreated cells, time 0. Panel B: Time-dependent effect of the phorbol esther phorbol myristate acetate (PMA $50 \mathrm{ng} / \mathrm{ml}$ ) upon NGF content of cultured human mastocytic HCM-1 cells. Western blot analysis of cell lysates measuring intracellular NGF.

Panel C: Densitometric analysis from western blot for time-dependent NGF protein expression in HMC-1 treated with PMA $50 \mathrm{ng} / \mathrm{ml}$. Results are expressed as percent variation versus control values. Vertical bars are means $\pm \mathrm{SE} ; * \mathrm{p}<0.05$ vs. CTRL (one-way ANOVA followed by the least significance Duncan's test). CTRL: untreated cells

Figure 3. Inhibitory effect of graded concentrations of the cannabinoid palmytoylethanolamide (PEA) upon 24 hrs phorbol myristate acetate (PMA)-induced release of NGF from cultured human mastocytic HCM-1 cells. CTRL: untreated cells; PMA: PMA alone 50 ng/ml; PEA: PEA alone; PEA + PMA: combined treatment. Vertical bars are means \pm SE; *p $<0.05$ vs. CTRL; ${ }^{\S}$ p $<0.05$ vs. PMA; (one-way ANOVA followed by the least significance Duncan's test).

Figure 4. Panel A: Effect of the cannabinoid palmytoyl-ethanolamide (PEA; $50 \mu \mathrm{g} / \mathrm{ml})$ on the phorbol esther phorbol myristate acetate (PMA; $50 \mathrm{ng} / \mathrm{ml}$ for $24 \mathrm{hrs}$ )-induced NGF release from cultured human mastocytic HCM-1 cells. Vertical bars are means \pm SE; ${ }^{*} p<0.05$ vs. CTRL; 
$* * \mathrm{p}<0.05$ vs. PMA (one-way ANOVA followed by the least significance Duncan's test). CTRL: untreated cells. Panel B: Effect of the cannabinoid palmytoyl-ethanolamide (PEA; $50 \mu \mathrm{g} / \mathrm{ml})$ on the phorbol esther phorbol myristate acetate (PMA; $50 \mathrm{ng} / \mathrm{ml}$ for $24 \mathrm{hrs}$ )-induced NGF release from cultured human mastocytic HCM-1 cells. Western blot analysis of cell lysates measuring intracellular NGF content. Panel C: Densitometric analysis from western blot for NGF protein expression in HMC-1 treated with PMA $50 \mathrm{ng} / \mathrm{ml}$. Results are expressed as percent variation versus control value. Vertical bars are means $\pm \mathrm{SE}$; $*$ p <0.05 vs. CTRL; and vs. PEA + PMA (one-way ANOVA followed by the least significance Duncan's test). CTRL: untreated cells.

Figure 5. Immunoflorescence analysis of NGF content in HMC-1 cells in culture, untreated (CTRL), treated with phorbol myristate acetate (PMA; $50 \mathrm{ng} / \mathrm{ml}$ ), treated with palmytoylethanolamide (PEA; $50 \mathrm{ug} / \mathrm{ml}$ ), or with a combination of the two substances (PMA + PEA). PEA was added to the cultures $1 \mathrm{~h}$ before PMA. (Magnification: 20x).

Figure 6. Panel A: Proliferation tests on human umbilical vein endothelial cells (HUVEC) treated with graded concentrations of conditioned media originating from HMC-1 cells challenged with phorbol myristate acetate (PMA; $50 \mathrm{ng} / \mathrm{ml}$ for $24 \mathrm{hrs}$ ). Panel B: Proliferation tests on human umbilical vein endothelial cells (HUVEC), preincubated with a NGF neutralizing monoclonal antibody and treated with graded concentrations of conditioned media originating from HMC-1 cells challenged with PMA (50 ng/ml for $24 \mathrm{hrs}$ ); Panel C: Proliferation tests on human umbilical vein endothelial cells (HUVEC) treated with graded concentrations of conditioned media originating from HMC-1 cells challenged with PMA (50 ng/ml for $24 \mathrm{hrs}$ ) and pretreated with PEA $50 \mu \mathrm{g} / \mathrm{ml}$. Vertical bars are means $\pm \mathrm{SE} ; * \mathrm{p}<0.05$ vs. CTRL; **p<0.05 vs. PMA (one-way ANOVA followed by the least significance Duncan's test). CTRL: untreated HUVEC. 
Figure 7. Upper panels: Reverse transcriptase polymerase chain reaction of the mRNA, either of the two cannabinoid receptors CB1 and CB2 (left gel), or the orphan receptor GPR55 (right gel), in human mastocytic HMC-1 cells. 100 bp are markers columns. Lower panels: western blot analysis of the corresponding proteins. The human cortical cell line HNC was used as a positive control; bidistilled water $\left(\mathrm{H}_{2} \mathrm{O}\right)$ was used as a negative control.

Figure 8. Upper panels: Time course of the effect of the transfection of human mastocytic HMC-1 cells with either the positive or the negative small interfering RNAs (respectively GPR55 $\mathrm{RNAi}^{+}$and GPR55 $\mathrm{RNAi}^{-}$) on GPR55 protein expression in cell lysates, measured by means of western blot analysis. Lower panels: Densitometric analysis from western blot for GPR55 protein expression in HMC-1 transfected with GPR55 $\mathrm{RNAi}^{+}$and GPR55 $\mathrm{RNAi}^{-}$. Results are expressed as percent variation versus control value

Figure 9. Effects of the cannabinoid palmytoyl-ethanolamide ((PEA; $50 \mu \mathrm{g} / \mathrm{ml})$ on phorbol myristate acetate (PMA; $50 \mathrm{ng} / \mathrm{ml}$ for $24 \mathrm{hrs}$ ) -induced NGF release from HCM-1 cells transfected for $30 \mathrm{~h}$ with either the positive (light grey histograms) or the negative (dark grey histograms) dominant small interfering RNAs (respectively $\mathrm{RNAi}^{+}$and $\mathrm{RNAi}^{-}$). Vertical bars are means $\pm \mathrm{SE}$; $*_{\mathrm{p}}<0.05$ vs. respective CTRL; ** $\mathrm{p}<0.05$ vs. respective PMA alone (one-way ANOVA followed by the least significance Duncan's test). 


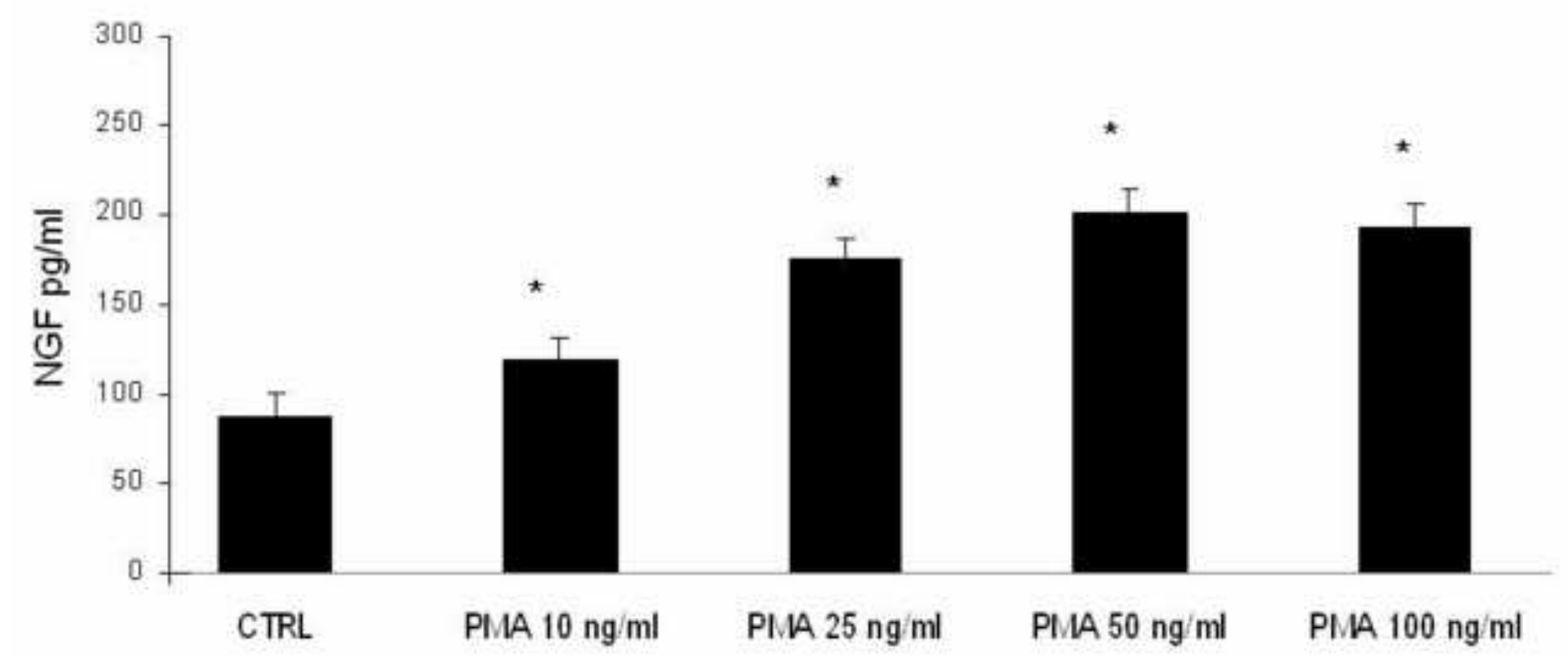


A
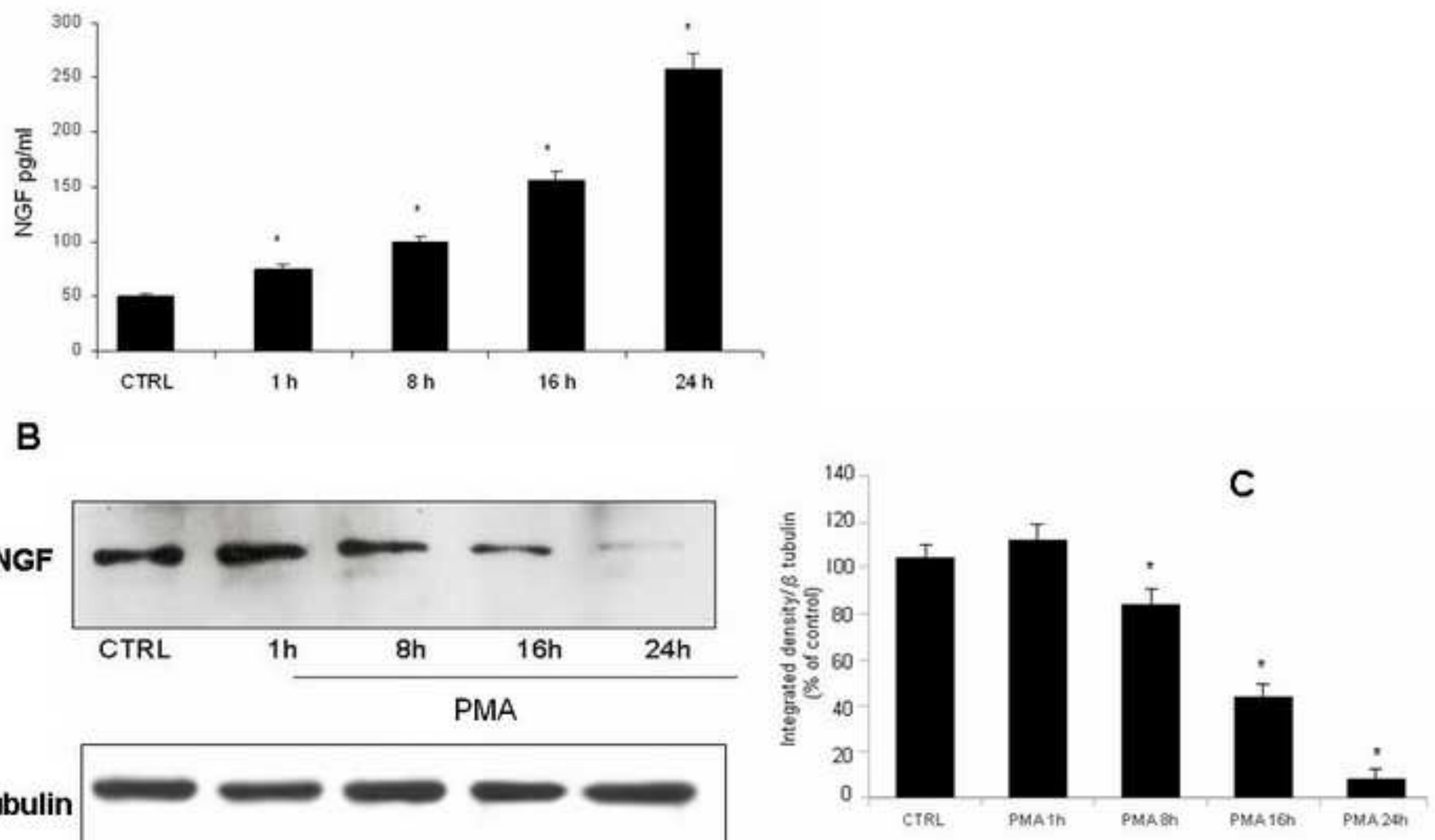

B

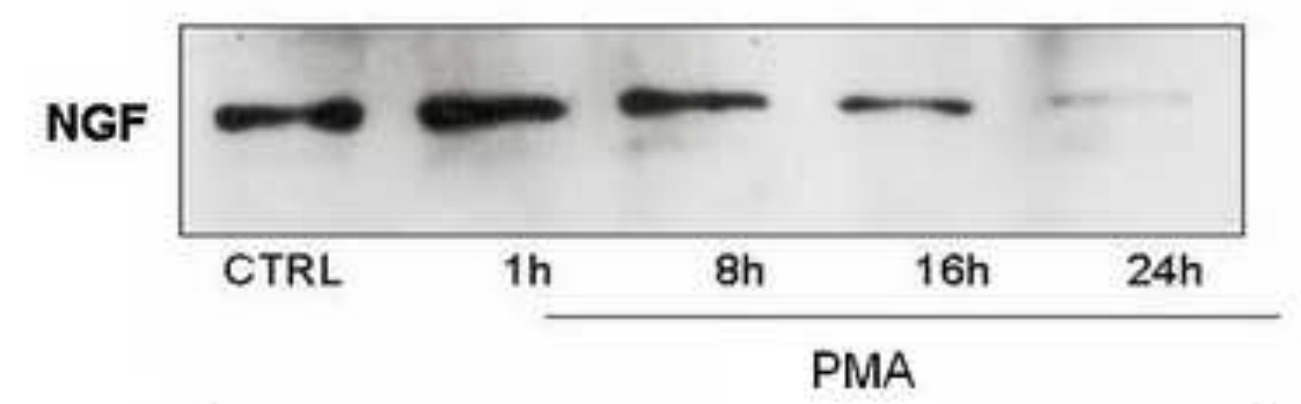

Tubulin

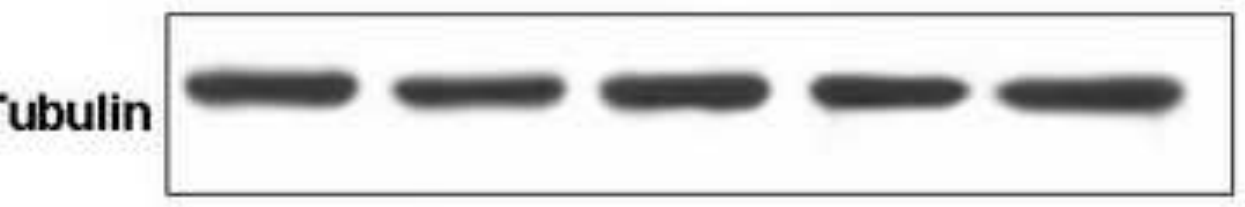




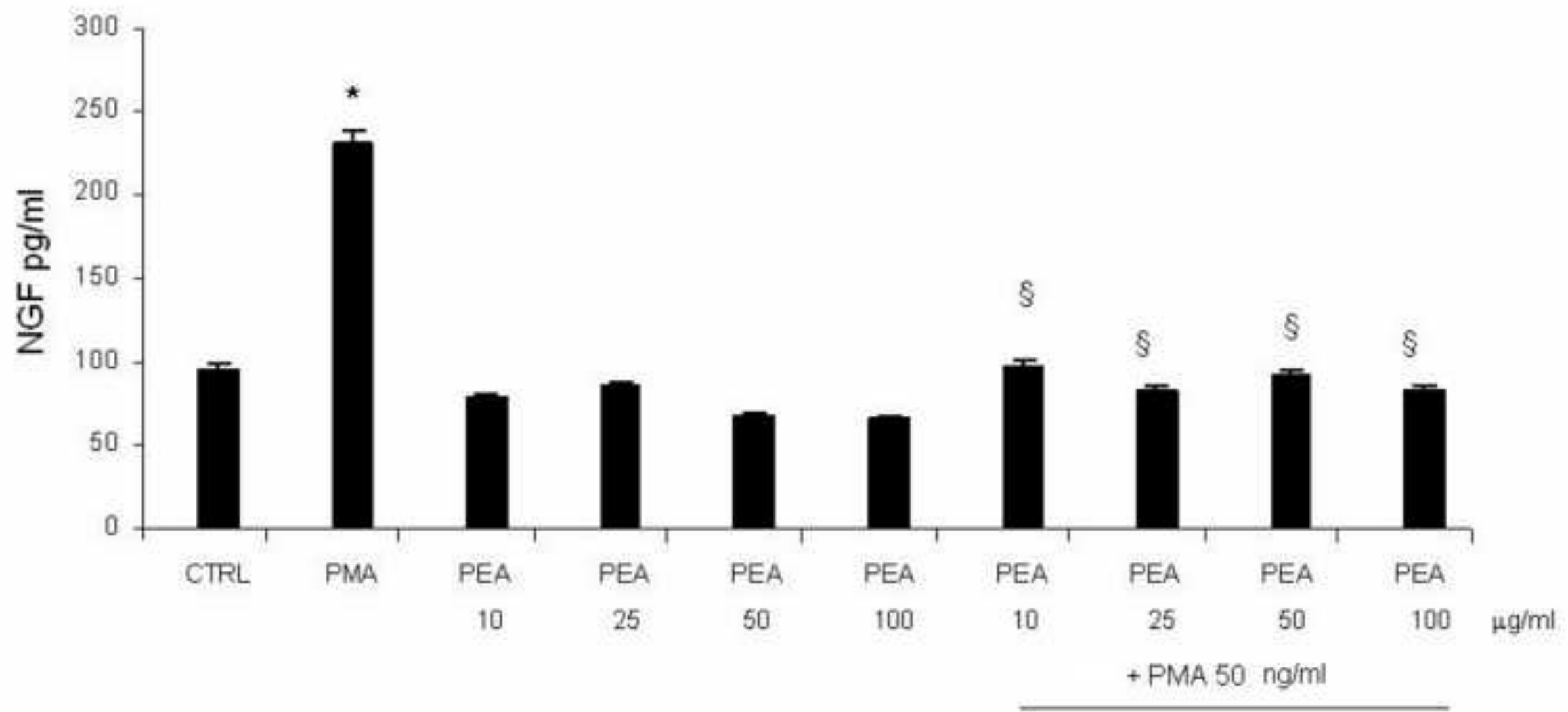



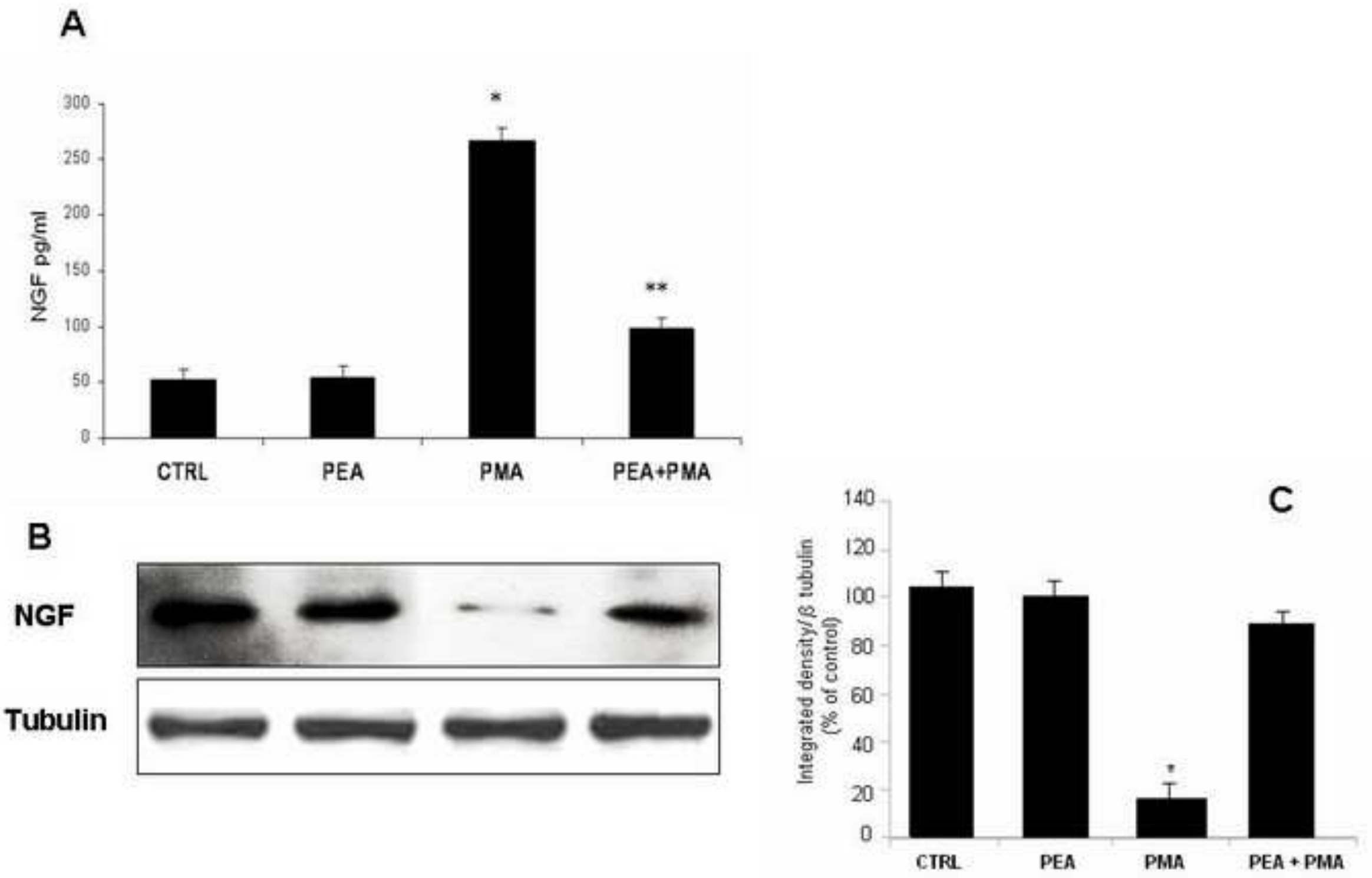

B

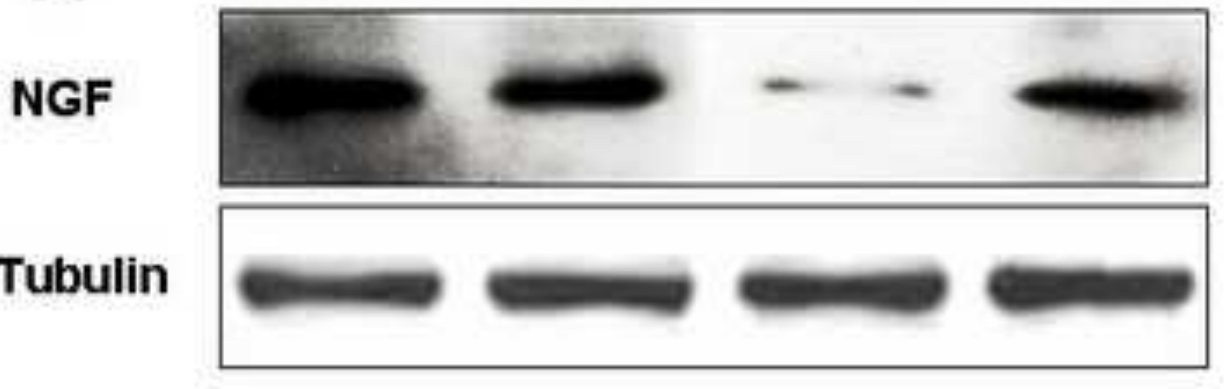




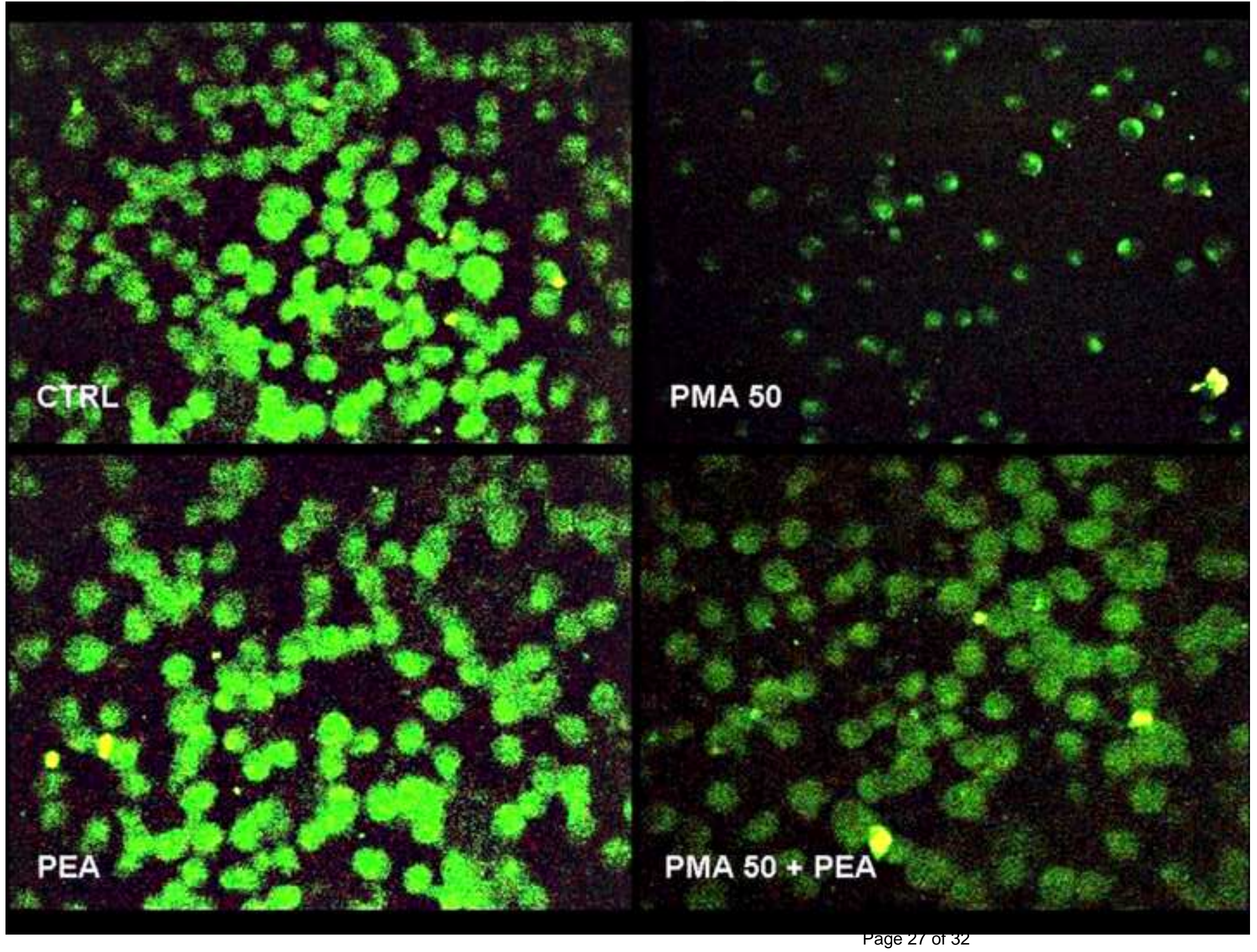

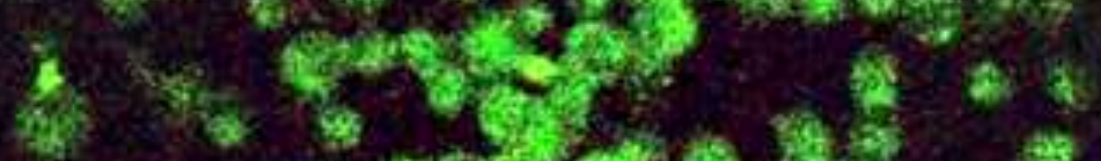

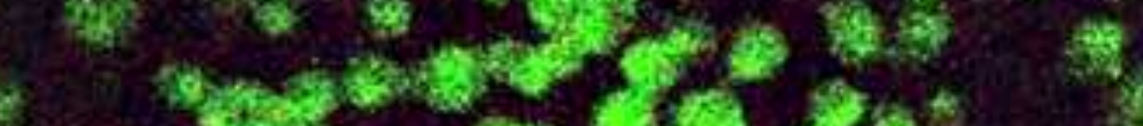

of 30 in

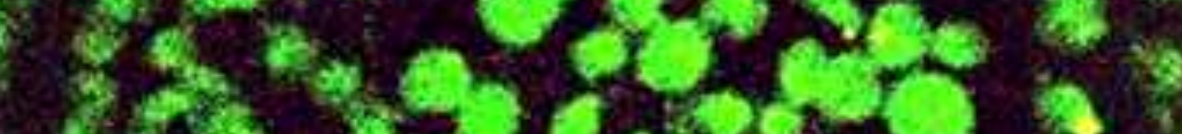
por to Est
PMA 50 + PEA

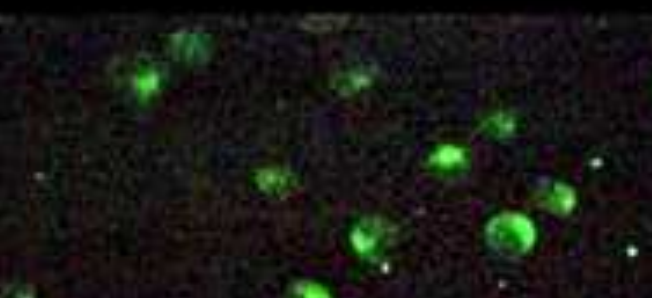

$$
\begin{aligned}
& 3
\end{aligned}
$$$$
\rightarrow
$$

\&ys

.



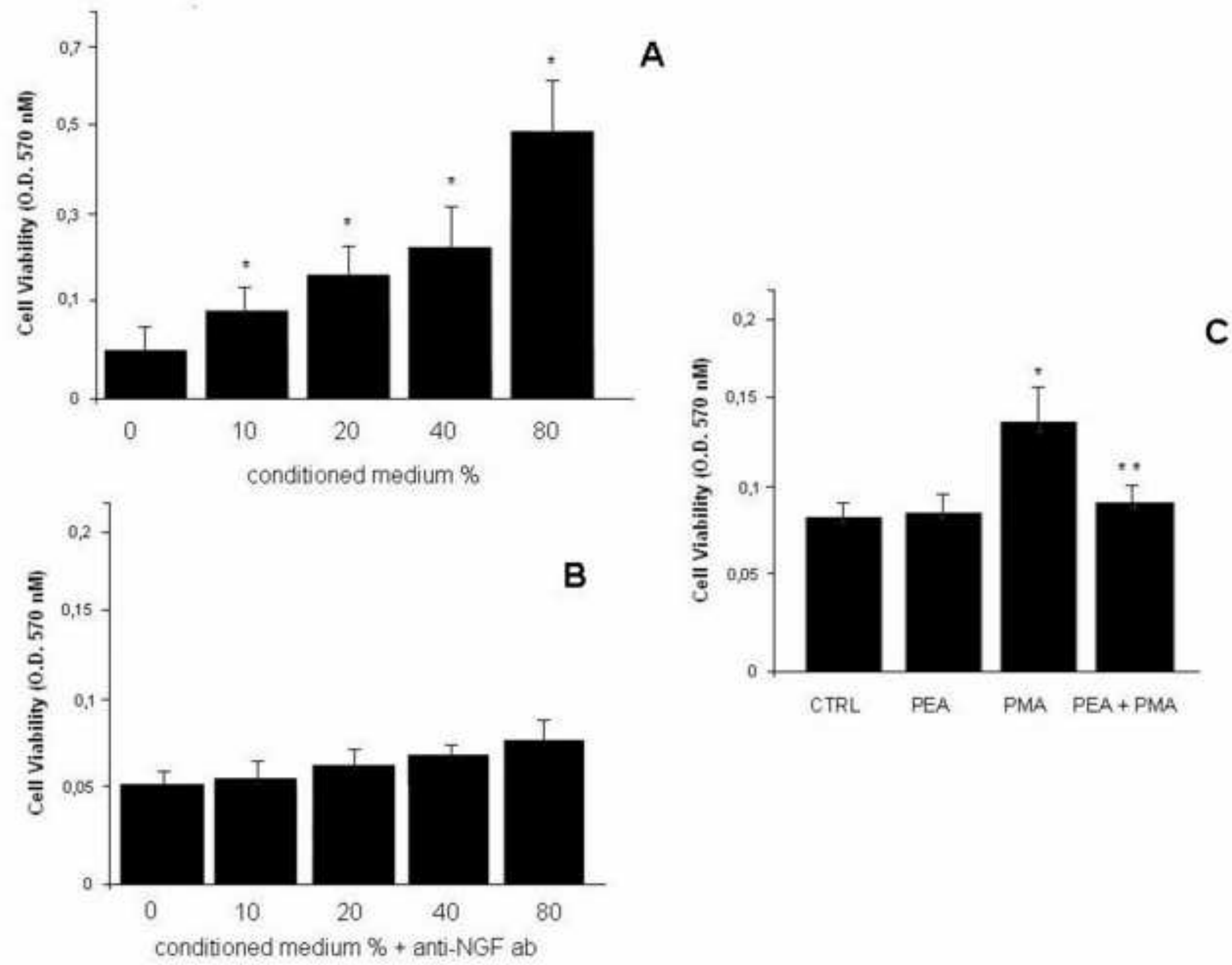

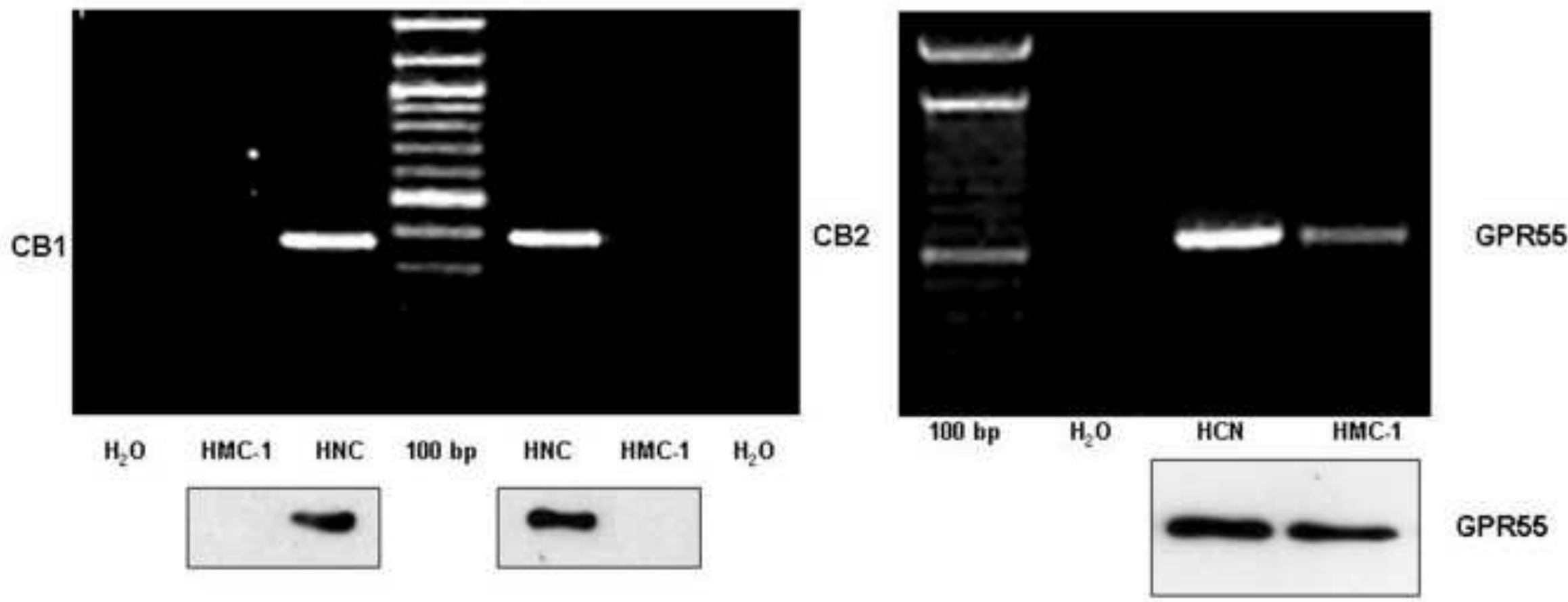

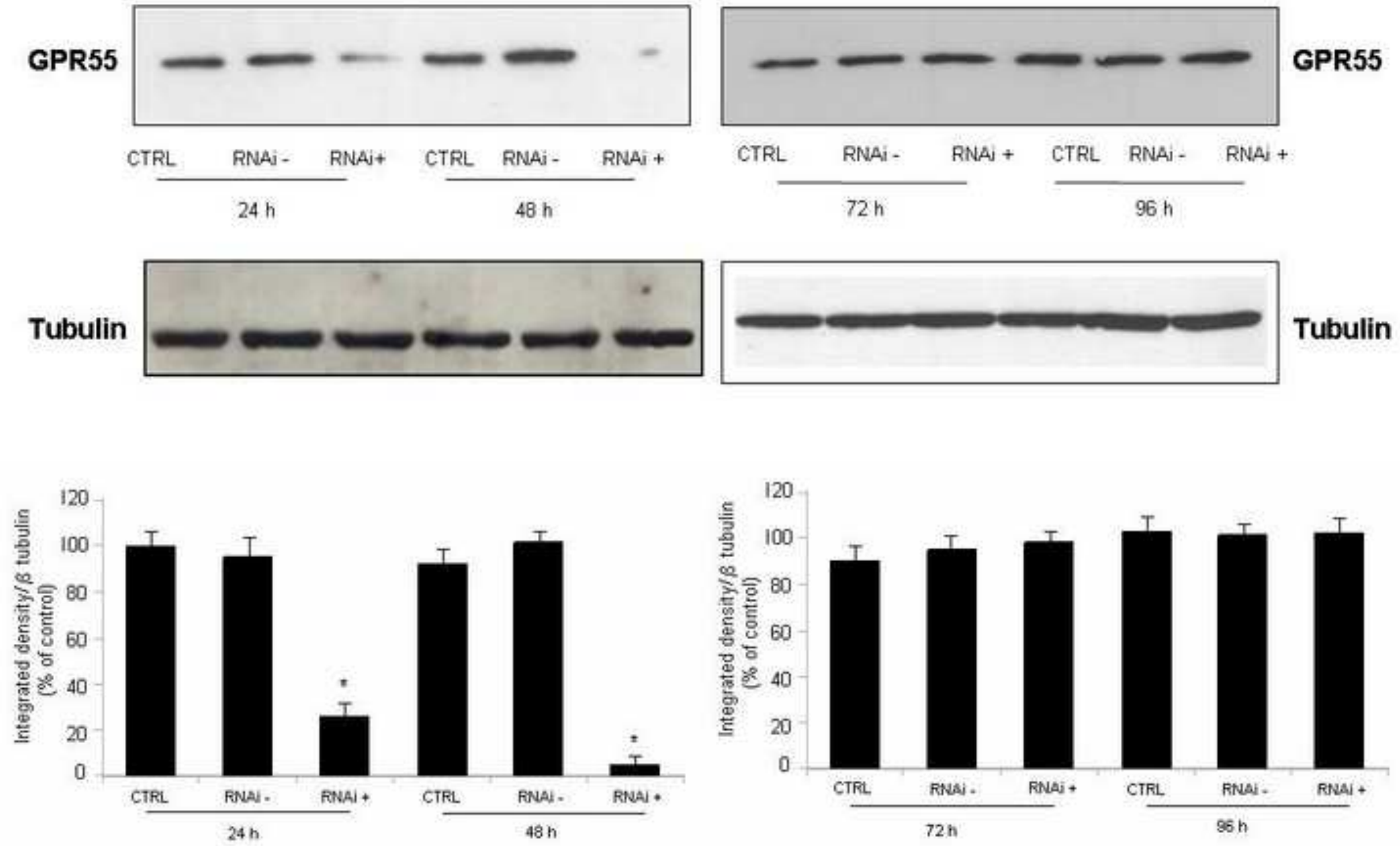


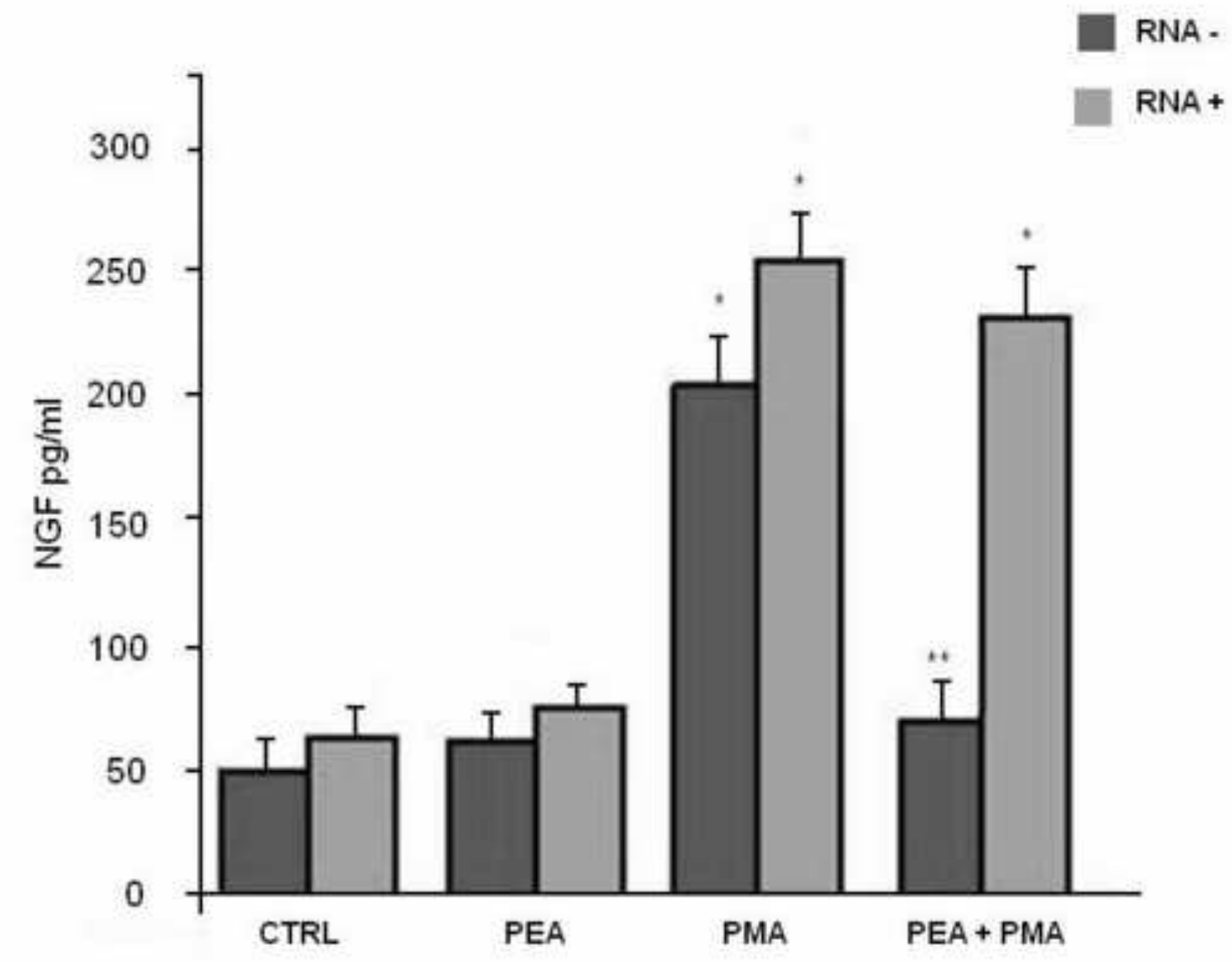

rage 31 оा 32 


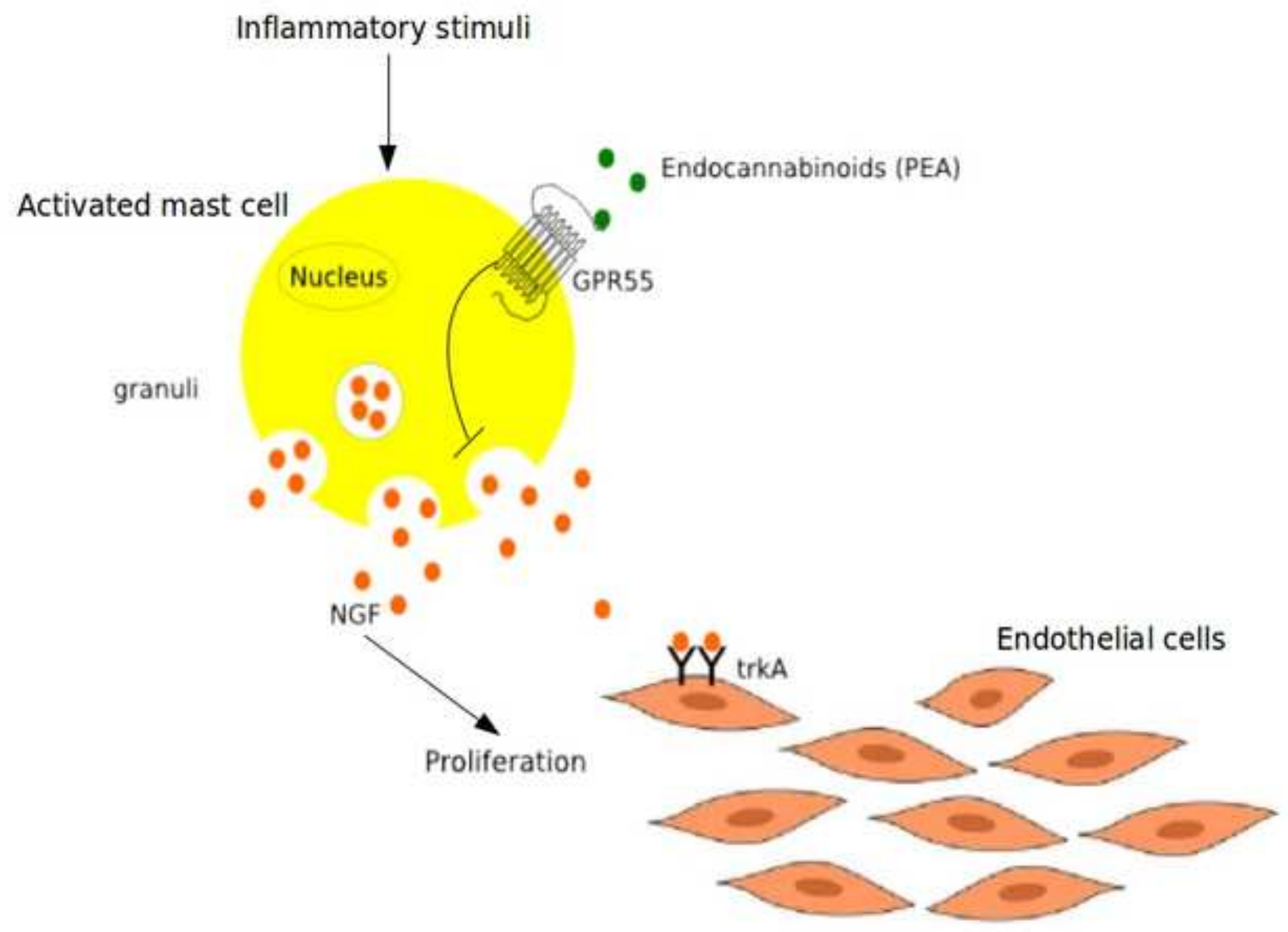

